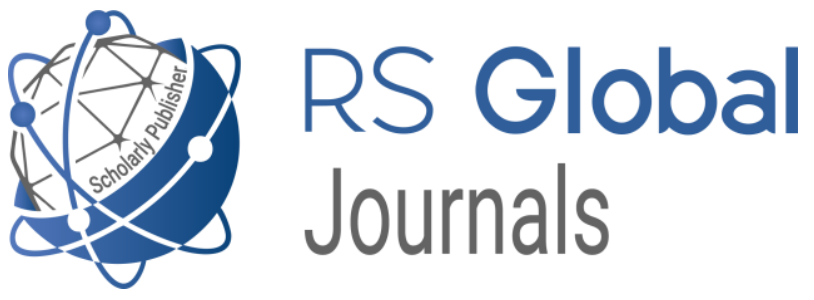

Scholarly Publisher

RS Global Sp. z O.O.

ISNI: 0000000484952390

Dolna 17, Warsaw, Poland 00-773

Tel: +48226022703

Email: editorial_office@rsglobal.pl

JOURNAL International Journal of Innovative Technologies in Social Science

p-ISSN 2544-9338

e-ISSN 2544-9435

PUBLISHER RS Global Sp. z O.O., Poland

ARTICLE TITLE SOME SECURITY CHALLENGES FOR GEORGIA

AUTHOR(S) Kuprashvili Henri

Kuprashvili Henri. (2021) Some Security Challenges for Georgia.

ARTICLE INFO International Journal of Innovative Technologies in Social

Science. 3(31). doi: 10.31435/rsglobal_ijitss/30092021/7677

DOI https://doi.org/10.31435/rsglobal_ijitss/30092021/7677

RECEIVED 03 August 2021

ACCEPTED 09 September 2021

PUBLISHED 13 September 2021

LICENSE

This work is licensed under a Creative Commons Attribution

4.0 International License.

(C) The author(s) 2021. This publication is an open access article. 


\title{
SOME SECURITY CHALLENGES FOR GEORGIA
}

\author{
Kuprashvili Henri, Doctor of Political Sciences, Professor, Faculty of Law and International \\ Relations, Georgian Technical University, Georgia, \\ ORCID ID: https://orcid.org/0000-0002-7013-1407
}

DOI: https://doi.org/10.31435/rsglobal_ijitss/30092021/7677

\section{ARTICLE INFO}

Received 03 August 2021

Accepted 09 September 2021

Published 13 September 2021

\section{KEYWORDS}

National security, Information age, politics, Georgia, political term.

\begin{abstract}
Important is the fact that the transition from the industrial age of humanity to the information age and the transformation of information into the dominant the process of the development of civilization as a main strategic resource, accordingly, the incredible development of information-telecommunication technologies has shown unprecedented changes and trends in the world politics, military and other fields of the 21 st century. In the new era, the security of modern Georgia, as well as other countries, is generally conditioned by many new challenges and threats. Moreover, the provision of its national security is to some extent also defined by the world of values of national selfdetermination, spiritual life, morality, culture and history.
\end{abstract}

Citation: Kuprashvili Henri. (2021) Some Security Challenges for Georgia. International Journal of Innovative Technologies in Social Science. 3(31). doi: 10.31435/rsglobal_ijitss/30092021/7677

Copyright: () 2021 Kuprashvili Henri. This is an open-access article distributed under the terms of the Creative Commons Attribution License (CC BY). The use, distribution or reproduction in other forums is permitted, provided the original author(s) or licensor are credited and that the original publication in this journal is cited, in accordance with accepted academic practice. No use, distribution or reproduction is permitted which does not comply with these terms.

Introduction. The political history of the world proves that the existence of states, survival of them and the settle of a worthy place in the international arena is related to as far as the country has the ability to solve new problems facing the state and thereby, be ready to respond to each new challenge in a continuous mode. That is why ensuring the national security is the subject of eternal care for the country. The issue of national security is the number one of the most vitally important problems, which is caused by various circumstances (Kuprashvili 2019). The fact that the issue of resolving the security has always been, is and will be one of the most important priority needs for human beings. Also important is the fact that the transition from the industrial age of humanity to the information age and the transformation of information into the dominant the process of the development of civilization as a main strategic resource; accordingly, the incredible development of information-telecommunication technologies has shown unprecedented changes and trends in the world politics, military and other fields of the 21 st century.

Georgia's security challenges in a new era. In the new era, the security of modern Georgia, as well as other countries, is generally conditioned by many new challenges and threats (MacFarlane 2012). Moreover, the provision of its national security is to some extent also defined by the world of values of national self-determination, spiritual life, morality, culture and history. The global challenges of the information age have revealed the modern trends, containing the serious threats, which are reflected in national security:

1. sharp separation between the state and public interests, as well as between foreign and domestic policy; gradually reducing the influence of states: a) facilitate the penetration of state borders; b) multiplication processes of transnational corporations and non-governmental actors and the growth of their influence etc.;

2. On the background of information-telecommunication and other technological scientific achievements, new specific realities were created, new types and forms of threats, their area of operation and spheres were expanded and diversified. For example, in terms of complexity and diversity, the issues of increasing the scale of the threat posed from cyber-terrorism have become actual in Georgia, which 
posed Georgia's national security against a completely new challenge and inevitable threat, which requires a special attention on the protection of the air-land-sea sphere, ensuring the cyber security of the country and the protection of the cyberspace sphere. Therefore, it is necessary to strengthen the country's readiness in the direction of international cooperation in face of the threat of cyber terrorism for the perfect functioning of a modern held system based on relevant legislation.

3. In the process of deepening globalization, the nature, form and scale of crimes have changed significantly; therefore the fight against transnational threats has become especially important; after the launch of the Europe-Asia Transport Corridor in Georgia, the scale of transnational threats has increased significantly, the danger of crimes turning into a transit country, the interest of international organizational criminals in Georgia.

Georgian problem of terminology. Here, we would like to touch on the issues to use of some security-related terms, as incorrect wording of the term can lead to many misunderstandings, which is clearly seen in the example of Georgia.

Recently, in Georgia, the terms "ushishroeba" (Security) and "usaprtkhoeba" (Safety) are sometimes used in inappropriate contexts, even at the legislative level. However, the content, meaning and rules of use of both terms have been clearly defined in the speech and writing of Georgians for a long time. For example, the use of the term "ushishroeba" (Security) is confirmed by the written sources, 15 centuries historical tradition that have reached us. In the 20th century, this was further strengthened by the authoritative Georgian linguistics, when it scientifically established the context and area of use of this term. According to Georgian sources (historical, theological-hagiographic, ancient artistic, including translated literature, etc.), since the 5th century, the term "ushishroeba" (Security) is traditionally used only in the socio-political context (ushishroeba (Security) of state, country, society, government, human, etc.). This term was used by famous Georgian hagiographers, writers, historians, scientists, political, military and public figures (Kartlis Tskhovreba 2014). So, from the 5 th century to the $10 \mathrm{~s}$ of the 21 st century, the whole society and clergy, Iakob Tsurtaveli ${ }^{1}$ or Leonti Mroveli $^{2}$, Solomon Dodashvili ${ }^{3}$ or Ilia Chavchavadze ${ }^{4}$, Ivane Javakhishvili ${ }^{5}$ or Ambrosi Khelaia, ${ }^{6}$ Arnold Chikobava ${ }^{7}$ or Ilia II, ${ }^{8}$ Zviad Gamsakhurdia ${ }^{9}$ or Eduard Shevardnadze, ${ }^{10}$ Mikheil Saakashvili ${ }^{11}$ or an ordinary citizen used this term only in the socio-political context.

And now, just 15-17 years ago, the tendentious and voluntary actions of contemporary politicians, unqualified, unprofessional and unilaterally educated people in power, started a deplorable trend, as a result of which the aboriginal Georgian word "ushishroeba" (Security) was arbitrarily declared an undesirable term and it was removed from use; instead, they use the word "usaprtkhoeba" (Safety) with different meanings. That is, one term "ushishroeba" (Security) is used to denote two events with different meanings, for example, the term "erovnuli ushishroeba" (National Security) was replaced by the term "erovnuli usaprtkhoeba" (National Safety) and so on.

The tendency may have been understandable if linguists, specialists in this field, to raise this issue, but due to the non-specialists and contemporaries be active and engage the public with their own subjective opinion it is unacceptable.

Therefore, it is better for Georgians not to follow the contemporaries and not to violate the historical tradition and to use the norms scientifically established by linguists and these terms in the appropriate context:

\footnotetext{
${ }^{1}$ 5th-century Georgian religious writer and priest from Tsurtavi.

${ }^{2}$ The 11 th-century Georgian chronicler.

${ }^{3}$ Georgian philosopher, journalist, historian, grammarian, belletrist and enlightener (1805-1836).

${ }^{4}$ Georgian public figure, journalist, publisher, writer and poet who spearheaded the revival of the Georgian national movement in the second half of the 19th century and played a major role in the creation of Georgian civil society during the Russian rule of Georgia. He is Georgia's "most universally revered hero."

${ }^{5}$ Georgian historian and a linguist whose voluminous works heavily influenced the modern scholarship of the history and culture of Georgia. He was also one of the founding fathers of the Tbilisi State University (1918)

${ }^{6}$ The Catholicos-Patriarch of All Georgia from 1921 to 1927.

${ }^{7}$ Georgian linguist and philologist.

${ }^{8}$ The Catholicos-Patriarch of All Georgia and the spiritual leader of the Georgian Orthodox Church.

${ }^{9}$ Georgian politician, dissident, scholar, and writer who became the first democratically elected President of Georgia in the post-Soviet era.

${ }^{10}$ Minister of Foreign Affairs of the Soviet Union (1985-1991), President of Georgia (1992-2003).

${ }^{11}$ Georgian and Ukrainian politician; The third President of Georgia (2004-2013).
} 
1. The term "ushishroeba" (Security) should be used if the neutralization (prevent) of the threat (danger) requires socio-political activities, the formulation and implementation of sociopolitical measures (policy development, concept, planning, etc.) or is related to people, society and with the socio-political activities of the state.

Depending on the source of origin and the content of the activity, the terms are used, for example: National Security; National Security Council; State Security; International Security; Political Security; Military Security; Information Security - Other Contents in Information Safety; Social Security; Environmental Security; Educational and Scientific-Technical Security; Technological Security; Demographic Security, etc.

2. The term "usaprtkhoeba" (Safety) should be used when the threat (danger) is of natural, man-made or industrial nature and legal, socio-economic, organizational-technical, hardwareprogram, sanitary-hygienic, medical-prophylactic and other measures are taken to neutraliza (prevent) it. Here, too, the terms: Occupational safety and health (OSH), Occupational safety, Road traffic safety; Railway System Safety; Land Transport Safety; Aviation safety; Construction site safety; Maritime safety; Transport safety; Viral Safety and Control; Computer Safety; Ecological safety; Fire safety; Field Safety; Industrial Safety (but the other is "Industrial Security"); Radiation Safety and Protection; Sanitary Safety; Safety Supplies; Safety Equipment; Technical safety; Chemical Safety; Electrical safety (but the other is "energy security"); Nuclear Security and so forth.

In this case, the term threat (danger), which can harm the population, the environment, etc., derives from the peculiarities of natural, man-made, industrial and work processes (earthquakes, largescale catastrophes, industrial accidents, fires, natural disasters, epizootics, epiphytotics, power stations, mines, enterprises, machinery-equipment, computer and network systems, substances, working methods, environmental conditions, labor organization, etc.) and is physical, chemical, biological, physiological and other character.

By the way, like the Georgian language, the term "Security" in English is used in the sociopolitical context: "National Security", "Security Council", " Security Information", and the term "Safety" as in Georgian language used in the context of natural, man-made or industrial nature: "Occupational Safety", "Road Safety", "Safety belts" etc. In some other languages, the situation is different, for example, in Russian only one term "Безопасность" (bezopasnost) is used regardless of the content and nature of the origin and neutralization of the threat and what it has to do with sociopolitical activities, natural, man-made, industrial and work processes: "Национальная Безопасность", "Техническая Безопасность" and etc.

Conclusions. Against the background of the information age, Georgia's aspiration to become a full-fledged participant in international relations should be considered as one of the defining necessary preconditions for the systematic improvement of the national security policy. Principles and norms of international political cooperation and relations in the issues of ensuring the national security, standards of conduct of states for agreed and effective cooperation, etc. require appropriate refinement of modern challenges. On this background, the national security policy implemented in the system, comprehensive international political relations and legal regulation will significantly increase the effectiveness of the fight against internal and external threats, will contribute to the security of national security and international political relations.

\section{REFERENCES}

1. Kuprashvili, Henri. 2019. Shevardnadze's Geostrategic Carambola. World Science. 4(44), Vol.3. Retrieved from https://doi.org/10.31435/rsglobal_ws/30042019/6484

2. MacFarlane, S. Neil. 2012. Georgia: National Security Concept versus National Security. Published in association with Center for Social Sciences, Tbilisi. Retrieved from http://css.ge/wpcontent/uploads/2019/07/neil_security_eng.pdf

3. Kuprashvili, Henri and Sharashenidze, Teimuraz. 2005. Political Aspects of the Formation of the National Information System in Post-Communist Georgia. Published by The Council for Research in Values and Philosophy. Washington. Chapter XI. P. 133-141. ISBN-13: 978-1-56518-224-0 (pbk.). Retrieved from https://books.google.ge/books?id=qzkttrhVe9gC\&pg=PA133\&lpg=PA133\&dq=Political+Aspects+of+the+For mation+of+the+National+Information+System+in+Post-

Communist+Georgia\&source=bl\&ots=J6DPFsHwqx\&sig=ZVzqUkcsg5Ia4BtKHaqbpBunG5Y\&hl=ru\&redir_e $\mathrm{sc}=\mathrm{y} \# \mathrm{v}=$ onepage $\& \mathrm{q}=$ Polit $\& \mathrm{f}=$ false

4. Kartlis Tskhovreba - A History of Georgia. 2014. Language English, Artanuji Publishing, Tbilisi. Retrieved from https://archive.org/details/kartliscxovreba_201409/page/n15/mode/2up 